\title{
Cytochrome P450 2A13 3375C>T gene polymorphism in a Turkish population
}

\author{
Zuhal Uçkun Șahinoğulları' \\ 'Mersin University, Faculty of Pharmacy, Department of Pharmaceutical Toxicology, Mersin, Turkey
}

ORCID IDs of the authors: Z.U.S. 0000-0002-3244-4103

Cite this article as: Uckun Sahinogulları, Z. (2020). Cytochrome P450 $2 A 13$ 3375C >T gene polymorphism in a Turkish population. Istanbul Journal of Pharmacy, 50 (3), 181-187.

\begin{abstract}
Background and Aims: The polymorphisms in genes encoding xenobiotic-metabolizing enzymes may change the metabolic activation of various xenobiotics and therefore may affect individuals' susceptibility to xenobiotics-induced toxic effects. Cytochrome P450 2A13 (CYP2A13) is an important CYP enzyme predominantly expressed in the human respiratory tract. CYP2A13 metabolizes the xenobiotics and bioactivation of several carcinogens. The present study aimed to determine the allele and genotype frequencies of CYP2A13 3375C $>T$ polymorphism in a Turkish population and also to compare the obtained results with those of various populations.

Methods: CYP2A13 3375C >T polymorphism was determined in 93 healthy Turkish individuals using the polymerase chain reaction-restriction fragment length method.

Results: The frequencies of $C C, C T$ and $T T$ genotypes were $89.2 \%, 9.7 \%$ and $1.1 \%$, respectively. The frequencies of $C$ and $T$ alleles were $94.1 \%$ and $5.9 \%$, respectively. The genotype frequencies did not deviate from the Hardy-Weinberg equilibrium. Significant differences were observed when comparing the results found with those of various populations, especially those of populations with black ancestry (excluding Tunisian).

Conclusion: This study can provide valuable data for further studies investigating the role of this polymorphism concerning the susceptibility to xenobiotics-induced toxic effects, including cancer, and may be used as a control group for such studies and also may contribute to toxicogenetic and epidemiological studies.
\end{abstract}

Keywords: CYP2A13 3375C>T, genetic polymorphism, Arg257Cys, Turkish population

\section{INTRODUCTION}

Human cytochrome P450s (CYPs) account for the metabolism of therapeutic agents and bioactivation of numerous carcinogens (Kim et al., 2018). CYP2A is a subfamily of CYPs that play an important role in the bioactivation of chemicals. The CYP2A gene subfamily contains two functional genes, CYP2A13 and CYP2A6, and a nonfunctional gene, CYP2A7 (Fukami, Nakajima, Sakai, Katoh, \&Yokoi, 2007). CYP2A13 and CYP2A6 consist of 494 amino acids (Fukami, Nakajima, Matsumoto, Zen, Oda, \& Yokoi, 2010) and the protein and nucleotide sequences of CYP2A13 are quite similar to CYP2A6 with 93.5\% and 95.3\% identity, respectively (Zhou, Liu, \& Chowbay, 2009). CYP2A6 is chiefly expressed in the human liver, while CYP2A13 is mostly expressed in the human respiratory tract, at the highest level in the nasal mucosa, followed by the trachea and lungs (Fukami et al., 2007; Tamaki et al., 2011a). In addition, CYP2A13 is expressed in a range of human tissues that include the uterus, testis, prostate, mammary gland and brain (Zhou et al., 2009).

CYP2A13 plays a significant role in the metabolic activation of many procarcinogens (Zhou et al., 2009). The most effective enzyme in the metabolic activation of 4-(methylnitrosamino)-1-(3-pyridyl)-1-butanone (NNK) that is the main tobacco-specific procarcinogen is 
CYP2A13 (Cheng, Chen, Zhang, Zhou, Wang, \& Zhou, 2004; Zhou et al., 2009). Furthermore, CYP2A13 metabolizes nicotine, cotinine, coumarin, aflatoxin $B_{1}$, mycotoxin (Zhou et al., 2009), hexamethylphosphoramide (HMPA), N,N-dimethylaniline (DMA), Nnitrosomethylphenylamine (NMPhA) (Sharma, Ahuja, Panda, \& Khullar, 2010), 3-N-nitrosoguvacoline, 3-methylindole (skatole), 3-(N-nitrosomethylamino)propionaldehyde, N-nitrosonornicotine (NNN), bergapten (5-methoxypsoralen), N-nitrosopyrrolidine (Alzahrani, \& Rajendran, 2020), N-nitrosodiethylamine, methyl tert-butyl ether, 2,6-dichlorobenzonitrile, 2-methoxyacetophenone (2'-MAP) (Su, Bao, Zhang, Smith, Hong, \& Ding, 2000; Zhou et al., 2009), 4-aminobiphenyl, toluene styrene, naphthalene (Fukami et al., 2010). In addition, CYP2A13 is responsible for the metabolism of theophylline and phenacetin, which are two typical CYP1A2 substrates (Zhou et al., 2009).

The CYP2A13 enzyme is encoded by the CYP2A13 gene located in a CYP gene cluster on chromosome 19 (Tamaki et al., 2011a). Hitherto, nine allelic variants and many single nucleotide polymorphisms (SNPS) have been described in the CYP2A13 gene (http-1: https://www.pharmvar.org/gene/CYP2A13). One of the important SNPs in the CYP2A13 gene is non-synonymous 3375C > T polymorphism (rs8192789) (Cheng et al., 2004), which is a transition from $C$ to $T$ at nucleotide 3375 in exon 5 (Sharma et al., 2010). This polymorphism is in linkage with functional substitution in the exon 1 of CYP2A13 gene, Arg25GIn (rs8192784) (Timofeeva et al., 2009), and the CYP2A13*2 allele represents either one or both variations of $3375 \mathrm{C}>T$ leading to Arg257Cys and 74G>A leading to Arg25Gln (Wang, He, Shen, Wang, \& Hong , 2006; Zhou et al., 2009). The Arg257Cys variant has been reported to be approximately $50 \%$ less active compared to the Arg-257 enzyme (Timofeeva et al., 2009). This decline may be elucidated by the location of the Arg at the 257 position, which is conservative in the CYP2As and which is located near the carboxyl end of the G-helix (Cauffiez et al., 2005; Zhou et al., 2009). The Arg257Cys polymorphism is functionally important, and it has been reported that this polymorphism could ensure some prevention against xenobiotic toxicity to carriers with homozygous for the Cys257 allele (Zhang et al., 2002). However, this association is controversial and this polymorphism should be studied in several ethnic groups.

Genetic variations in CYP enzymes may have the greatest effect on the fate of carcinogenic chemicals and therapeutic drugs (Kim et al., 2018). These variations in CYP enzymes may lead to susceptibility to diseases as well as protection from disease or reduced risk of illness (Elfaki, Mir, Almutairi, \& Duhier, 2018). Genetic variations that affect the CYP2A13 enzyme function may give rise to inter-individual variability in susceptibility to a variety of diseases, including lung cancer (Tamaki et al., 2011a). The CYP2A13 enzyme plays a significant role in the metabolism of numerous carcinogens, drug, and other xenobiotics. Due to differentiation of enzyme activity in variant CYP2A13 alleles, inter- and intra-population diversity may be an important clinical problem in toxicity and response to xenobiotics metabolized by the CYP2A13 enzyme.

It is known that gene polymorphisms of CYPs indicate significant distinctions in frequency among different racial and ethnic groups (Korytina, Kochetova, Akhmadishina, Viktorova, \& Victorova , 2012; Uckun Sahinogullari, 2020). Thus, the objective of the current study was to detect the allele and genotype frequencies of 3375C>T SNP in CYP2A13 gene (rs8192789) encoding CYP2A13 enzyme in a healthy Turkish population and to compare the obtained findings with the results of previously reported populations, and thus to provide useful data for toxicogenetic and epidemiological studies.

\section{MATERIALS AND METHODS}

\section{Samples}

The DNA samples isolated from the previous study (22/10/2015, protocol no: 2015/317) were included in the current survey. The present study was also approved by the Ethics Committee of Mersin University (19/02/2020, protocol no: 2020/169). This investigation was performed on the DNA samples of 93 healthy and unrelated Turkish individuals aged between 1865 years. The study was executed according to Good Clinical Practices and the Helsinki Declaration.

\section{Genotyping}

CYP2A13 3375 C>T polymorphism was conducted as per the method defined by Chen et al. (2004) with minor modifications. Polymerase chain reaction (PCR) amplification for $\mathrm{CY}$ P2A13 was performed using the forwad and reverse primers: 5'- CCTGGACAGATGCCTTTAACTCCG-3' and 5'- TGGCTTTGCACCTGCCTGCACT-3', respectively. PCR was done in a 20- $\mu \mathrm{L}$ reaction mixture which contained 300 to 500 ng of genomic DNA, 10 pmol of each primer, $10 \times$ PCR buffer, $1.5 \mathrm{mM} \mathrm{MgCl}_{2}$, $0.2 \mathrm{mM}$ each deoxynucleotide triphosphate and 1.20 unit of Taq polymerase (Fermentase) on MiniAmp Plus Thermal Cycler (Thermo Fisher, USA). The PCR process was as follows: $95^{\circ} \mathrm{C}$ for 3 min for initial denaturation and then 35 cycles of $95^{\circ} \mathrm{C}$ for 30 $\mathrm{sec}, 63^{\circ} \mathrm{C}$ for $45 \mathrm{sec}, 72^{\circ} \mathrm{C}$ for $30 \mathrm{sec}$, followed by a final elongation at $72^{\circ} \mathrm{C}$ for $5 \mathrm{~min}$. A negative control containing no DNA was included in each PCR analysis to ensure that the reagents used did not contain contaminating DNA. The PCR products (332 bp) were electrophoresed on a 1\% agarose gel including ethidium bromide $(0.5 \mu \mathrm{g} / \mathrm{mL})$ which made the products visible and then the $10 \mu \mathrm{L}$ PCR product was cut in 15 minutes at $37^{\circ} \mathrm{C}$ using $10 \mathrm{U}$ of Fast Digest Hhal restriction enzyme with the proper buffer in total volume of $20 \mu \mathrm{L}$. The variant genotype (TT) was digested to $332 \mathrm{bp}$ fragment while the wild type genotype (CC) was digested to 233 and 99 bp fragments (Figure 1). $1.5 \%$ agarose gel with ethidium bromide was used to evaluate the digested fragments. $10 \%$ of the samples were reanalyzed at random for quality assurance and which provided 100\% concordance.

\section{Statistical analysis}

The allelic and genotypic frequencies were calculated using the genotype counting method. The expected and observed frequencies of CYP2A13 were compared using the chi-square $\left(X^{2}\right)$ test based on the Hardy-Weinberg equilibrium. A comparison of the frequencies of this study with the results of previously reported populations was made using the chi-square test. The baseline properties between genotypes were compared using chi-square test and Mann-Whitney $U$ test, where appropriate. Statistical analyses were carried out with IBM SPSS 
A)

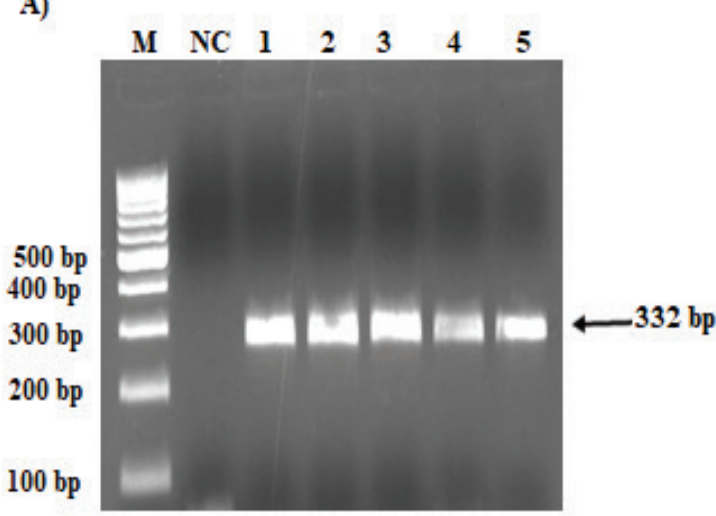

B)

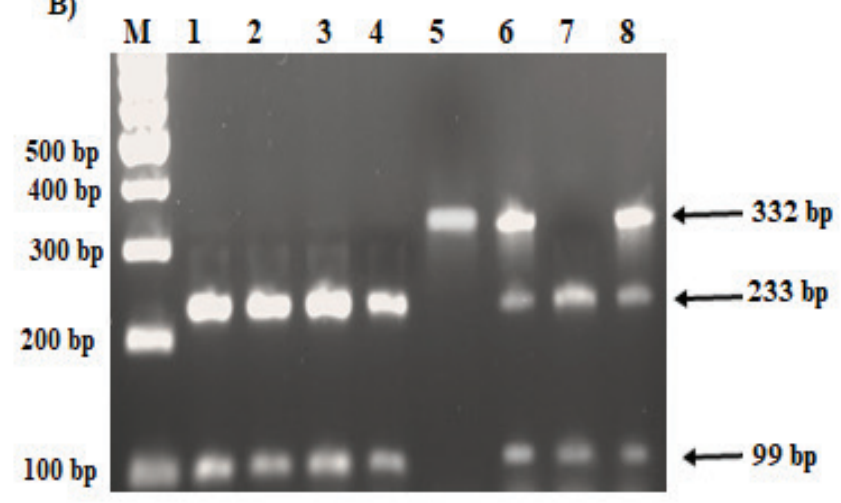

Figure 1. Agarose gel images of CYP2A13 3375C>T polymorphism using polymerase chain reaction (PCR) (A) and restriction fragment length polymorphism (RFLP) (B). Lane M: Marker (100 bp). For A (PCR) part; NC: Negative control, Lane 1-5: PCR product (332 bp). For B (RFLP) part; Lane 1-4,7: wild type genotype (233, 99 bp), Lane 5: mutant genotype (332 bp), Lane 6,8: heterozygous genotype (332, 233, 99 bp).

25.0 computer software for Windows. $p<0.05, \mathrm{p}<0.001$ and $p<0.0001$ were considered statistically significant.

\section{RESULTS}

CYP2A13 3375C > T polymorphism was conducted in 93 healthy unrelated individuals. Of the 93 individuals, 40 (43\% of all participants) were male and 53 (57\%) were female. The mean age with standard deviation (SD) of the participants was $28.34 \pm$ 10.14 years, the mean body weight with SD was $69.64 \pm 13.52$ $\mathrm{kg}$, the mean height with SD was $169.25 \pm 8.62 \mathrm{~cm}$ and the mean body mass index (BMI) with SD was $24.22 \pm 3.77 \mathrm{~kg} / \mathrm{m}^{2}$. No significant difference was noted between the genotypes and baseline properties ( $p>0.05$ ) (Table 1).

\section{Table 1. Baseline properties of the individuals included in the study.}

\begin{tabular}{|lcccc|}
$\begin{array}{l}\text { Baseline } \\
\text { properties }\end{array}$ & Total & CC & $\begin{array}{c}C T+ \\
T T\end{array}$ & $\begin{array}{c}p \\
\text { value }\end{array}$ \\
\hline n (\%) & & & & \\
\hline Gender & & & & \\
Male & $40(43)$ & $37(92.5)$ & $3(7.5)$ & $0.379^{\mathrm{a}}$ \\
Female & $53(57)$ & $46(86.8)$ & $7(13.2)$ & \\
Age range (years) & & & & \\
$<$ 40 & 77 & 70 & 7 & $0.256^{\mathrm{a}}$ \\
$\geq 40$ & 16 & 13 & 3 & \\
mean \pm SD & & & & \\
\hline Body weight (kg) & $69.64 \pm$ & $70.39 \pm$ & $62.75 \pm$ & $0.194^{\mathrm{b}}$ \\
& 13.52 & 13.93 & 5.78 & \\
Height (cm) & 169.25 & $169.45 \pm$ & $167.50 \pm$ & $0.627^{\mathrm{b}}$ \\
& \pm 8.62 & 8.23 & 12.16 & \\
BMI (kg/m²) & $24.22 \pm$ & $24.42 \pm$ & $22.49 \pm$ & $0.164^{\mathrm{b}}$ \\
& 3.77 & 3.86 & 2.43 & \\
\hline
\end{tabular}

Data expressed as mean \pm standard deviation (mean \pm SD). BMI: Body mass index; ${ }^{a}$ : Chi-square test; ${ }^{b}$ : Mann-Whitney $U$ test.
As shown in Table 2, the frequencies of CC, CT and TT genotypes were $89.2 \%, 9.7 \%$ and $1.1 \%$, respectively. The $C$ and $T$ allele frequencies were obtained as $94.1 \%$ and $5.9 \%$, respectively. The genotype frequencies were consistent with HardyWeinberg equilibrium $\left(X^{2}=1.58, p>0.05\right)$.

\section{Table 2. Distribution of CYP2A13 $3375 C>T$ gene polymorphism in a healthy Turkish population.}

\begin{tabular}{|c|c|c|c|c|}
\hline Genotype & $\begin{array}{c}n \\
\text { (Observed) }\end{array}$ & $\begin{array}{c}\text { Genotype } \\
\text { frequencies, } \\
\%\end{array}$ & $\begin{array}{c}n \\
\text { (Expected) }\end{array}$ & $\begin{array}{c}\text { Allele } \\
\text { frequencies, } \\
\%\end{array}$ \\
\hline$C C$ & 83 & 89.2 & 82.3 & C: 94.1 \\
\hline$C T$ & 9 & 9.7 & 10.4 & $\begin{array}{c}T: 5.9 \\
X^{2}: 1.58\end{array}$ \\
\hline TT & 1 & 1.1 & 0.3 & $\begin{array}{l}d f=1 \\
p>0.05\end{array}$ \\
\hline Total & 93 & 100 & 93 & \\
\hline
\end{tabular}

\section{DISCUSSION}

In the current study, the genotype and allele frequencies of $C Y$ P2A13 3375C $>$ T polymorphism in a healthy Turkish population were investigated and compared with various populations. The CC, CT and TT genotype frequencies of CYP2A13 polymorphism were $89.2 \%, 9.7 \%$ and $1.1 \%$, respectively and thus the frequencies of C and $T$ allele were $94.1 \%$ and $5.9 \%$, respectively.

The findings of this study were compared with the results of the 1000 Genomes Project (http-2: https://www.internationalgenome.org/1000-genomes-browsers/) and previously reported populations as shown in Table 3 (Cauffiez et al., 2005; Cheng et al., 2004; Fujieda et al., 2003; Herr, Bettendorf, Denschlag, Keck, \& Pietrowski, 2006; Song, Xing, Zhang, Li, Liu, \& Qiao, 2009; Wang et al., 2003; Zhang et al., 2002). The allele frequencies of CYP2A13 3375C>T polymorphism were dominant in Black ancestry, including Black, Yoruba in Ibadan, Nigeria (YRI), Esan in Nigeria (ESN), Luhya in Webuye, Kenya (LWK), African Caribbeans in Barbados (ACB) populations, ranging from 
Table 3. Distribution of genotype and allele frequencies of CYP2A13 3375C $>T$ polymorphism in different ethnic populations.

\begin{tabular}{|c|c|c|c|c|c|c|c|c|}
\hline \multirow[t]{2}{*}{ Ethnicity } & \multirow[t]{2}{*}{ Population } & \multirow{2}{*}{$\begin{array}{c}\text { Sample } \\
\text { size }\end{array}$} & \multicolumn{3}{|c|}{$\begin{array}{c}\text { Genotype frequencies } \\
\mathrm{n}(\%)\end{array}$} & \multicolumn{2}{|c|}{$\begin{array}{l}\text { Allele frequencies } \\
\mathrm{n}(\%)\end{array}$} & \multirow[t]{2}{*}{ References } \\
\hline & & & $C C$ & $C T$ & $T T$ & $C$ & $T$ & \\
\hline \multicolumn{9}{|l|}{ White } \\
\hline \multirow{9}{*}{ 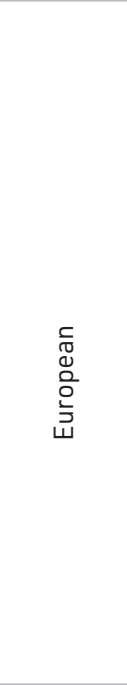 } & Whites & 52 & $50(96.2)$ & $2(3.8)$ & $0(0.0)$ & $102(98.1)$ & $2(1.9)$ & $\begin{array}{l}\text { Zhang et al., } \\
2002\end{array}$ \\
\hline & Turkish & 93 & $83(89.2)$ & $9(9.7)$ & $1(1.1)$ & $175(94.1)$ & $11(5.9)$ & $\begin{array}{l}\text { The present } \\
\text { study }\end{array}$ \\
\hline & French* & 52 & $52(100)$ & $0(0.0)$ & $0(0.0)$ & $52(100)$ & $0(0.0)$ & $\begin{array}{c}\text { Cauffiez et al., } \\
2005\end{array}$ \\
\hline & $\begin{array}{l}\text { British in England } \\
\text { and Scotland (GBR)* }\end{array}$ & 91 & $90(98.9)$ & $1(1.1)$ & $0(0.0)$ & $181(99.5)$ & $1(0.5)$ & $\begin{array}{l}1000 \text { Genomes }^{\text {Project }} \\
\text { Proje }\end{array}$ \\
\hline & $\begin{array}{l}\text { Iberian populations } \\
\text { in Spain (IBS)* }\end{array}$ & 107 & $105(98.1)$ & $2(1.9)$ & $0(0.0)$ & $212(99.1)$ & $2(0.9)$ & $\begin{array}{l}1000 \text { Genomes } \\
\text { Project }^{\mathrm{a}}\end{array}$ \\
\hline & Germany* & 243 & $237(97.5)$ & $6(2.5)$ & $0(0.0)$ & $480(98.8)$ & $6(1.2)$ & Herr et al., 2006 \\
\hline & $\begin{array}{l}\text { Finnish in Finland } \\
\text { (FIN) }\end{array}$ & 99 & $96(97.0)$ & $3(3.0)$ & $0(0.0)$ & $195(98.5)$ & $3(1.5)$ & $\begin{array}{l}1000 \text { Genomes } \\
\text { Project }^{\mathrm{a}}\end{array}$ \\
\hline & Toscani in Italy (TSI) & 106 & $102(95.3)$ & $5(4.7)$ & $0(0.0)$ & $209(97.7)$ & $5(2.3)$ & $\begin{array}{l}1000 \text { Genomes }^{\text {Project }} \\
\text { Pres }\end{array}$ \\
\hline & Hispanic & 52 & $46(88.5)$ & $6(11.5)$ & $0(0.0)$ & $98(94.2)$ & $6(5.8)$ & $\begin{array}{l}\text { Zhang et al., } \\
2002\end{array}$ \\
\hline \multirow{4}{*}{ 怘 } & $\begin{array}{l}\text { Mexican Ancestry } \\
\text { in Los Angeles, } \\
\text { California (MXL)* }\end{array}$ & 64 & $64(100)$ & $0(0.0)$ & $0(0.0)$ & $128(100)$ & $0(0.0)$ & $\begin{array}{l}1000 \text { Genomes }^{\text {Project }} \\
\text { Pa }\end{array}$ \\
\hline & $\begin{array}{l}\text { Peruvian in Lima, } \\
\text { Peru (PEL)* }\end{array}$ & 85 & $84(98.8)$ & $1(1.2)$ & $0(0.0)$ & $169(99.4)$ & $1(0.6)$ & $\begin{array}{l}1000 \text { Genomes }^{\text {Project }}{ }^{\mathrm{a}} \\
\text { Pro }^{2}\end{array}$ \\
\hline & $\begin{array}{l}\text { Colombian in } \\
\text { Medellin, Colombia } \\
\text { (CLM) }\end{array}$ & 94 & $88(93.6)$ & $6(6.4)$ & $0(0.0)$ & $182(96.8)$ & $6(3.2)$ & $\begin{array}{l}1000 \text { Genomes } \\
\text { Project }^{a}\end{array}$ \\
\hline & $\begin{array}{l}\text { Puerto Rican in } \\
\text { Puerto Rico (PUR) }\end{array}$ & 104 & $92(88.5)$ & $11(10.6)$ & $1(0.9)$ & $195(93.8)$ & $13(6.2)$ & $\begin{array}{l}1000 \text { Genomes } \\
\text { Project }^{\mathrm{a}}\end{array}$ \\
\hline \multicolumn{9}{|l|}{ Asians } \\
\hline \multirow{10}{*}{ 岳 } & Asians & 52 & $44(84.6)$ & $8(15.4)$ & $0(0.0)$ & $96(92.3)$ & $8(7.7)$ & $\begin{array}{l}\text { Zhang et al., } \\
2002\end{array}$ \\
\hline & Japanese $e^{\star \star}$ & 192 & $192(100)$ & $0(0.0)$ & $0(0.0)$ & $384(100)$ & $0(0.0)$ & $\begin{array}{l}\text { Fujieda et al., } \\
2003\end{array}$ \\
\hline & $\begin{array}{c}\text { Japanese in Tokyo, } \\
\text { Japan (JPT) }\end{array}$ & 104 & $95(91.3)$ & $8(7.7)$ & $1(1.0)$ & $198(95.2)$ & $10(4.8)$ & $\begin{array}{l}1000 \text { Genomes }^{\text {Groject }} \\
\text { Projes }^{\mathrm{a}}\end{array}$ \\
\hline & $\begin{array}{c}\text { Southern Han } \\
\text { Chinese, China } \\
\text { (CHS) }\end{array}$ & 105 & $94(89.5)$ & $11(10.5)$ & $0(0.0)$ & $199(94.8)$ & $11(5.2)$ & $\begin{array}{l}1000 \text { Genomes }^{\text {Project }} \\
\text { Pa }\end{array}$ \\
\hline & Chinese & 258 & $230(89.1)$ & $27(10.5)$ & $1(0.4)$ & $487(94.4)$ & $29(5.6)$ & $\begin{array}{l}\text { Cheng et al., } \\
2004\end{array}$ \\
\hline & $\begin{array}{l}\text { Kinh in Ho Chi Minh } \\
\text { City, Vietnam (KHV) }\end{array}$ & 99 & 87 (87.9) & $11(11.1)$ & $1(1.0)$ & $185(93.4)$ & $13(6.6)$ & $\begin{array}{l}1000 \text { Genomes }^{\text {Project }} \\
\text { Pa }\end{array}$ \\
\hline & $\begin{array}{c}\text { Han Chinese in } \\
\text { Bejing, China (CHB) }\end{array}$ & 103 & $88(85.4)$ & $15(14.6)$ & $0(0.0)$ & $191(92.7)$ & $15(7.3)$ & $\begin{array}{l}1000 \text { Genomes } \\
\text { Project }^{\mathrm{a}}\end{array}$ \\
\hline & $\begin{array}{l}\text { Chinese Dai in } \\
\text { Xishuangbanna, } \\
\text { China (CDX) }\end{array}$ & 93 & 79 (84.9) & $14(15.1)$ & $0(0.0)$ & $172(92.5)$ & $14(7.5)$ & $\begin{array}{l}1000 \text { Genomes } \\
\text { Project }^{\mathrm{a}}\end{array}$ \\
\hline & Chinese & 212 & $180(84.9)$ & $31(14.6)$ & $1(0.5)$ & $391(92.2)$ & $33(7.8)$ & $\begin{array}{l}\text { Song et al., } \\
2009\end{array}$ \\
\hline & Chinese & 791 & $652(82.4)$ & $130(16.4)$ & $9(1.2)$ & $\begin{array}{l}1434 \\
(90.6)\end{array}$ & $\begin{array}{l}148 \\
(9.4)\end{array}$ & $\begin{array}{l}\text { Wang et al., } \\
2003\end{array}$ \\
\hline
\end{tabular}


Table 3. Continued.

\begin{tabular}{|c|c|c|c|c|c|c|c|c|}
\hline \multirow{3}{*}{$\begin{array}{l}\frac{c}{.0} \\
\frac{.0}{40} \\
\frac{1}{4} \\
\frac{1}{3} \\
\text { o }\end{array}$} & $\begin{array}{l}\text { Indian Telugu in the UK } \\
\text { (ITU) }\end{array}$ & 102 & $\begin{array}{c}96 \\
(94.1)\end{array}$ & $6(5.9)$ & $0(0.0)$ & $\begin{array}{c}198 \\
(97.1)\end{array}$ & $6(2.9)$ & $\begin{array}{l}1000 \text { Genomes } \\
\text { Project }^{\mathrm{a}}\end{array}$ \\
\hline & $\begin{array}{c}\text { Sri Lankan Tamil in the } \\
\text { UK (STU) }\end{array}$ & 102 & $\begin{array}{c}95 \\
(93.1)\end{array}$ & $7(6.9)$ & $0(0.0)$ & $\begin{array}{c}197 \\
(96.6)\end{array}$ & $7(3.4)$ & $\begin{array}{l}1000 \text { Genomes } \\
\text { Project }^{\mathrm{a}}\end{array}$ \\
\hline & $\begin{array}{l}\text { Punjabi in Lahore, } \\
\text { Pakistan (PJL) }\end{array}$ & 96 & $\begin{array}{c}80 \\
(83.3)\end{array}$ & $\begin{array}{c}15 \\
(15.6)\end{array}$ & $1(1.1)$ & $\begin{array}{c}175 \\
(91.1)\end{array}$ & $\begin{array}{c}17 \\
(8.9)\end{array}$ & $\begin{array}{l}1000 \text { Genomes } \\
\text { Project }^{a}\end{array}$ \\
\hline \multicolumn{9}{|l|}{ Black } \\
\hline \multirow{6}{*}{ 总 } & Black* & 52 & $\begin{array}{c}38 \\
(73.1)\end{array}$ & $\begin{array}{c}13 \\
(25.0)\end{array}$ & $1(1.9)$ & $\begin{array}{c}89 \\
(85.6)\end{array}$ & $\begin{array}{c}15 \\
(14.4)\end{array}$ & $\begin{array}{l}\text { Zhang et al., } \\
\qquad 2002\end{array}$ \\
\hline & Tunisian & 48 & $\begin{array}{c}44 \\
(91.7)\end{array}$ & $4(8.3)$ & $0(0.0)$ & $\begin{array}{c}92 \\
(95.8)\end{array}$ & $4(4.2)$ & $\begin{array}{l}\text { Cauffiez et al., } \\
2005\end{array}$ \\
\hline & $\begin{array}{l}\text { African Caribbeans in } \\
\text { Barbados }(\mathrm{ACB}) \star \star \star\end{array}$ & 96 & $\begin{array}{c}64 \\
(66.7)\end{array}$ & $\begin{array}{c}27 \\
(28.1)\end{array}$ & $5(5.2)$ & $\begin{array}{c}155 \\
(80.7)\end{array}$ & $\begin{array}{c}37 \\
(19.3)\end{array}$ & $\begin{array}{l}1000 \text { Genomes } \\
\text { Project }^{\mathrm{a}}\end{array}$ \\
\hline & $\begin{array}{l}\text { Yoruba in Ibadan, Nigeria } \\
\text { (YRI) }{ }^{\star \star \star}\end{array}$ & 108 & $\begin{array}{c}70 \\
(64.8)\end{array}$ & $\begin{array}{c}33 \\
(30.6)\end{array}$ & $5(4.6)$ & $\begin{array}{c}173 \\
(80.1)\end{array}$ & $\begin{array}{c}43 \\
(19.9)\end{array}$ & $\begin{array}{l}1000 \text { Genomes } \\
\text { Project }^{\mathrm{a}}\end{array}$ \\
\hline & 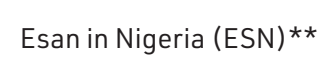 & 99 & $\begin{array}{c}61 \\
(61.6)\end{array}$ & $\begin{array}{c}32 \\
(32.3)\end{array}$ & $6(6.1)$ & $\begin{array}{c}154 \\
(77.8)\end{array}$ & $\begin{array}{c}44 \\
(22.2)\end{array}$ & $\begin{array}{l}1000 \text { Genomes } \\
\text { Project }^{\mathrm{a}}\end{array}$ \\
\hline & $\begin{array}{l}\text { Luhya in Webuye, Kenya } \\
(\text { LWK })^{\star \star}\end{array}$ & 99 & $\begin{array}{c}61 \\
(61.6)\end{array}$ & $\begin{array}{c}32 \\
(32.3)\end{array}$ & $6(6.1)$ & $\begin{array}{c}154 \\
(77.8)\end{array}$ & $\begin{array}{c}44 \\
(22.2)\end{array}$ & $\begin{array}{l}1000 \text { Genomes } \\
\text { Project }^{\mathrm{a}}\end{array}$ \\
\hline
\end{tabular}

14.4 to $22.2 \%$. The allele frequencies of these populations were predominantly determined to be higher compared to the Turkish population. Contrarily, the allele frequency of the Turkish population was similar to the Tunisian population with an allele frequency of $4.2 \%$.

The frequencies in European ancestry, including French, British in England and Scotland (GBR), Iberian populations in Spain (IBS) and Germany populations with a range of 0.0 to $1.2 \%$ were determined to be significantly lower compared to the frequencies in the Turkish population $(p<0.05)$, but no significant difference was observed between the results of this study and those of Whites, Finnish in Finland (FIN), Toscani in Italy (TSI) and Hispanic populations with a range from 1.5 to $5.8 \%$ ( $p>0.05$ ). In addition, there were no significant differences between the allele frequencies of the Turkish population and those of American ancestry, including Colombian in Medellin, Colombia (CLM) with 3.2\% allelic frequency and Puerto Rican in Puerto Rico (PUR) with 6.2\% allelic frequency ( $p>0.05)$. However, the results of the present study were significantly higher compared to those of other American ancestry, including Mexican Ancestry in Los Angeles, California (MXL) with $0.0 \%$ allelic frequency and Peruvian in Lima, Peru (PEL) with $0.6 \%$ allelic frequency $(p<0.05)$.

Furthermore, there were significant differences between the allele frequency of $0.0 \%$ in the Japanese population and that of the Turkish population $(p<0.0001)$. However, no significant differences were noted between the obtained results and those of populations with Asian ancestry, including, Asians, Japanese in Tokyo, Japan (JPT), Southern Han Chinese, China (CHS), Chinese, Kinh in Ho Chi Minh City, Vietnam (KHV), Han Chinese in Bejing, China (CHB), Chinese Dai in Xishuangbanna, China (CDX), Indian
Telugu in the UK (ITU), Sri Lankan Tamil in the UK (STU) and Punjabi in Lahore, Pakistan (PJL), ranging from 2.9 to $9.4 \%$.

As mentioned above, the allele frequency of CYP2A13 3375C>T is variable among different populations. Therefore, this polymorphism may cause intra- and inter- population variations in drugs, other xenobiotics toxicity and predisposition to various diseases.

Wang et al. (2003) investigated 724 patients with lung cancer and 791 healthy controls in the Chinese population for contribution of CYP2A13 Arg257Cys polymorphism to lung cancer risks with regard to tobacco smoking. The variant CYP2A13 genotypes (CT or $T T$ ) were reported to have a decreased risk of lung adenocarcinoma in relation to light tobacco smoking compared to the CYP2A13 CC genotype (odds ratio [OR]=0.23; 95\% confidence interval $[\mathrm{Cl}]=0.08-0.68 ; \mathrm{p}=0.008$ ). However, Arg257Cys polymorphism had no protection against lung squamous cell carcinoma. Herr et al. (2006) investigated the relationship between CYP2A13 3375C>T polymoprhism and the development of uterine leiomyoma in a case-control study consisting of 126 women with uterine leiomyoma and 243 controls and reported that this polymorphism had a significant association with uterine leiomyoma in a Caucasian population. In another case-control study consisting of 163 patients with bladder cancer and 161 healthy controls, Kumondai et al. (2016) examined the association between bladder cancer occurrence and CYP2A13 genetic polymorphisms in Japanese smokers and it was reported that the adjusted odds ratio for the CYP2A13*1/*2 genotype was $0.34(95 \% \mathrm{Cl}=0.17-0.69)$ and the presence of CYP2A13*2 had a relationship with a decline in the risk of bladder cancer. D'Agostino et al. (2008) examined whether the CYP2A13.2 protein has reduced expression levels and/or enzyme activity in the lung in comparison to CY- 
P2A13.1. It was reported that the CYP2A13.2 protein was 20 to $40 \%$ lower active compared to CYP2A13.1 with the substrates studied; which were NNK, HMPA, 2'-MPA, DMA and NMPhA. Additionally, the CYP2A13*2 allele was associated with an approximately $40 \%$ lower level of allelic expression than the CYP2A13*1 allele. Zhang et al. (2002) reported that the Arg257Cys variant had a 37 to $56 \%$ lower catalytic activity compared to the wild-type Arg-257 protein toward the substrates examined; NMPhA, DMA, 2'-MAP and HMPA and that Cys-257 had a $>2$-fold reduction in catalytic efficiency compared to Arg-257 for NNK. Furthermore, for CYP2A13*2 (Arg257Cys) and CYP2A13*8 (Asp158Glu), a decrease of 30 to $42 \%$ in coumarin 7-hydroxylation catalytic efficiency has been reported (Schlicht, Michno, Smith, Scott, \& Murphy, 2007).

Contrary to the studies mentioned above, Song et al. (2009) reported that in a case-control survey of 208 cases and 212 controls, no significant relationship was found between the CYP2A13 variant alleles (CT or TT) and bladder cancer risk in central China (OR=1.07; 95\% Cl: 0.63-1.81; $p=0.725)$. Timofeeva et al. (2009) found no significant relationship between the CYP2A13 rs8192789 polymorphism and the risk of lung cancer in Caucasian patients (OR=1.04; 95\% Cl=0.55-1.96; $p=0.9019)$ Furthermore, no significant relationship between CYP2A13 ( ${ }^{*} 1$ *10) genetic polymorphisms and lung cancer was reported in a Japanese population of 192 lung cancer patients and 203 controls (for CYP2A13*2 allele, crude OR=0.75; 95\% Cl=0.40-1.40; $p<0.05$ ) (Tamaki et al. $2011 \mathrm{~b}$ ). Jiang et al. (2004) examined the association between CYP2A13 genetic polymorphisms and the risk of developing nasopharyngeal cancer in the Cantonese population of southern China and found no association of the variant alleles contaning $3375 \mathrm{C}>T$ with nasopharyngeal cancer risk (for $3375 \mathrm{C}>T, \mathrm{OR}=0.85 ; 95 \% \mathrm{Cl}=0.59-1.22$ ). In addition, CYP2A13 3375C>T variant has been reported to not be associated with head and neck cancer susceptibility in a North Indian population ( $\mathrm{OR}=0.61 ; 95 \% \mathrm{Cl}=0.29-1.28 ; \mathrm{p}=0.189)$ (Sharma et al., 2010).

Genetic polymorphisms can affect the activities of enzymes that play a role in the metabolism of carcinogens, drugs and other xenobiotics, and can cause inter- and intra-population differences in susceptibility to various diseases, drug safety and efficacy, toxicities of xenobiotics.

\section{CONCLUSION}

The present study performs the frequencies of the CYP2A13 $3375 C>T$ polymorphism in a healthy Turkish population and a comparison of the obtained findings with those of other populations. Significant differences were observed in comparing the results found with those of some previously reported populations, especially those with black ancestry (excluding Tunisian). The results of this study can provide valuable data for further studies investigating the role of this polymorphism concerning susceptibility to xenobiotics-induced toxic effects, including cancer, and may even be used as a control group for such studies. Furthermore, the data of this study may improve toxicogenetic studies and contribute to epidemiological studies.
Peer-review: Externally peer-reviewed.

Author Contributions: Conception/Design of Study- Z.U.Ş.; Data ACquisition- Z.U.Ş.; Data Analysis/Interpretation- Z.U.Ş.; Drafting Manuscript- Z.U.Ş.; Critical Revision of Manuscript- Z.U.Ş.; Final Approval and Accountability- Z.U.Ş.

Ethics Committee Approval: This study was approved by the Ethics Committee of Mersin University. (date: 19/02/2020, number: 2020/169)

Informed Consent: The DNA samples used were obtained during the previous study, which was approved by Mersin University Ethics Committee (22/10/2015, protocol no: 2015/317). Informed consent form had been obtained while blood samples were taken from volunteers.

Conflict of Interest: The authors have no conflict of interest to declare.

Financial Disclosure: Authors declared no financial support.

\section{REFERENCES}

- $\quad$ Alzahrani, A. M., \& Rajendran, P. (2020). The multifarious link between cytochrome P450s and cancer. Oxidative Medicine and Cellular Longevity, 2020:3028387.

Cauffiez, C., Pottier, N., Tournel, G., Lo-Guidice, J. M., Allorge, D., Chevalier, D., Migot-Nabias, F., Kenani, A., \& Broly, F. (2005). CYP2A13 genetic polymorphism in French Caucasian, Gabonese and Tunisian populations. Xenobiotica, 35(7), 661-669.

- Cheng, X. Y., Chen, G. L., Zhang, W. X., Zhou, G., Wang, D., \& Zhou, H. H. (2004). Arg257Cys polymorphism of CYP2A13 in a Chinese population. Clinica Chimica Acta, 343(1-2), 213-216.

- D'Agostino, J., Zhang, X., Wu, H., Ling, G., Wang, S., Zhang, Q.Y., Liu, F., \& Ding, X. (2008). Characterization of CYP2A13*2, a variant cytochrome P450 allele previously found to be associated with decreased incidences of lung adenocarcinoma in smokers. Drug Metabolism and Disposition, 36(11), 2316-2323.

- $\quad$ Elfaki, I., Mir, R., Almutairi, F. M., \& Duhier, F. M. A. (2018). Cytochrome P450: Polymorphisms and Roles in Cancer, Diabetes and Atherosclerosis. Asian Pacific Journal of Cancer Prevention, 19(8), 2057-2070

- $\quad$ Fujieda, M., Yamazaki, H., Kiyotani, K., Muroi, A., Kunitoh, H., Dosaka-Akita, H., Sawamura, Y., \& Kamataki, T. (2003). Eighteen novel polymorphisms of the CYP2A13 gene in Japanese. Drug Metabolism and Pharmacokinetics, 18(1), 86-90.

- Fukami, T., Nakajima, M., Matsumoto, I., Zen, Y., Oda, M., \& Yokoi, T. (2010). Immunohistochemical analysis of CYP2A13 in various types of human lung cancers. Cancer Science, 101(4), 1024-1028.

Fukami, T., Nakajima, M., Sakai, H., Katoh, M., \& Yokoi, T. (2007). CYP2A13 metabolizes the substrates of human CYP1A2, phenacetin, and theophylline. Drug Metabolism and Disposition, 35(3), 335-339.

Herr, D., Bettendorf, H., Denschlag, D., Keck, C., \& Pietrowski, D. (2006). Cytochrome P2A13 and P1A1 gene polymorphisms are associated with the occurrence of uterine leiomyoma. Archives of Gynecology and Obstetrics, 274(6), 367-371.

- http-1: https://www.pharmvar.org/gene/CYP2A13. Accessed 10.04.2020.

- http-2: https://www.internationalgenome.org/1000-genomesbrowsers/. Accessed 03.04.2020.

- Jiang, J. H., Jia, W. H., Chen, H. K., Feng, B. J., Qin, H. D., Pan, Z. G., Shen, G. P., Huang, L. X., Feng, Q. S., Chen, L. Z., Lin, D. X., \& Zeng, Y. X. (2004). Genetic polymorphisms of CYP2A13 and its relationship to nasopharyngeal carcinoma in the Cantonese population. Journal of Translational Medicine, 2(1), 24. 
- Kim, V., Yeom, S., Lee, Y., Park, H. G., Cho, M. A., Kim, H., \& Kim, D. (2018). In vitro functional analysis of human cytochrome P450 2A13 genetic variants: P450 2A13*2, *3, *4, and *10. Journal of Toxicology and Environmental Health. Part A, 81 (12), 493-501.

- Korytina, G., Kochetova, O., Akhmadishina, L., Viktorova, E., \& Victorova, T. (2012). Polymorphisms of cytochrome p450 genes in three ethnic groups from Russia. Balkan Medical Journal, 29(3), 252-260.

- Kumondai, M., Hosono, H., Orikasa, K., Arai, Y., Arai, T., Sugimura, H., Ozono, S., Sugiyama, T., Takayama, T., Sasaki, T., Hirasawa, N., \& Hiratsuka, M. (2016). CYP2A13 Genetic Polymorphisms in Relation to the Risk of Bladder Cancer in Japanese Smokers. Biological \& Pharmaceutical Bulletin, 39(10), 1683-1686.

- $\quad$ Schlicht, K. E., Michno, N., Smith, B. D., Scott, E. E., \& Murphy, S. E. (2007). Functional characterization of CYP2A13 polymorphisms. Xenobiotica, 37(12), 1439-1449.

- Sharma, R., Ahuja, M., Panda, N., \& Khullar, M. (2010). Polymorphisms in CYP2A13 and UGT1A7 genes and head and neck cancer susceptibility in North Indians. Oral Diseases, 16(8), 760-768.

- $\quad$ Song, D. K., Xing, D. L., Zhang, L. R., Li, Z. X., Liu, J., \& Qiao, B. P. (2009). Association of NAT2, GSTM1, GSTT1, CYP2A6, and CYP2A13 gene polymorphisms with susceptibility and clinicopathologic characteristics of bladder cancer in Central China. Cancer Detection and Prevention, 32(5-6), 416-423.

- $\quad$ Su, T., Bao, Z., Zhang, Q. Y., Smith, T. J., Hong, J. Y., \& Ding, X. (2000). Human cytochrome P450 CYP2A13: predominant expression in the respiratory tract and its high efficiency metabolic activation of a tobacco-specific carcinogen, 4-(methylnitrosamino)-1-(3pyridyl)-1-butanone. Cancer Research, 60(18), 5074-5079.

- Tamaki, Y., Honda, M., Muroi, Y., Arai, T., Sugimura, H., Matsubara, Y., Kanno, S., Ishikawa, M., Hirasawa, N., \& Hiratsuka, M. (2011a) Novel single nucleotide polymorphism of the CYP2A13 gene in Japanese individuals. Drug Metabolism and Pharmacokinetics, 26(5), 544-547.
Tamaki, Y., Arai, T., Sugimura, H., Sasaki, T., Honda, M., Muroi, Y., Matsubara, Y., Kanno, S., Ishikawa, M., Hirasawa, N., \& Hiratsuka, M. (2011b) Association between cancer risk and drug-metabolizing enzyme gene (CYP2A6, CYP2A13, CYP4B1, SULT1A1, GSTM1, and GSTT1) polymorphisms in cases of lung cancer in Japan. Drug Metabolism and Pharmacokinetics, 26(5), 516-522.

Timofeeva, M. N., Kropp, S., Sauter, W., Beckmann, L., Rosenberger, A., Illig, T., Jäger, B., Mittelstrass, K., Dienemann, H.; LUCY-Consortium, Bartsch, H., Bickeböller, H., Chang-Claude, J. C., Risch, A., \& Wichmann, H. E. (2009). CYP450 polymorphisms as risk factors for early-onset lung cancer: gender-specific differences. Carcinogenesis, 30(7), 1161-1169.

- Uckun Sahinogullari, Z. (2020). Genetic polymorphism of CY$P 2 C 8^{*} 4$ in a healthy Turkish population. Medicine Science, 9(2), 314-319.

- Wang, S. L., He, X. Y., Shen, J., Wang, J. S., \& Hong, J. Y. (2006). The missense genetic polymorphisms of human CYP2A13: functional significance in carcinogen activation and identification of a null allelic variant. Toxicological Sciences, 94(1), 38-45.

Wang, H., Tan, W., Hao, B., Miao, X., Zhou, G., He, F., \& Lin, D. (2003). Substantial reduction in risk of lung adenocarcinoma associated with genetic polymorphism in CYP2A13, the most active cytochrome P450 for the metabolic activation of tobacco-specific carcinogen NNK. Cancer Research, 63(22), 8057-8061.

Zhang, X., Su, T., Zhang, Q. Y., Gu, J., Caggana, M., Li, H., \& Ding, $X$. (2002). Genetic polymorphisms of the human CYP2A13 gene: identification of single-nucleotide polymorphisms and functional characterization of an Arg257Cys variant. Journal of Pharmacology and Experimental Therapeutics, 302(2), 416-423.

- Zhou, S. F., Liu, J. P., \& Chowbay, B. (2009). Polymorphism of human cytochrome P450 enzymes and its clinical impact. Drug Metabolism Reviews, 41(2), 89-295. 